\title{
Formy adresatywne a otwieranie się społeczeństwa. Analiza norweskich dramatów XX wieku
}

\author{
Helena Garczyńska \\ Uniwersytet Gdański \\ finhg@univ.gda.pl
}

\section{Streszczenie}

Celem artykułu jest przyjrzenie sie pewnym zmianom $w$ komunikacji społecznej $w$ Norwegii, dotyczacym form adresatywnych, czyli słów $i$ wyrażeń używanych do zwracania się do rozmówcy. Ponieważ dramat wydaje się być najwłaściwszym materiałem do tego typu badań ze względu na nasycenie go formami deiktycznymi, typowymi dla dialogu mówionego, między innymi właśnie zaimkami i imionami własnymi, materiat do badań pochodzi z wybranych dramatów takich pisarzy ostatniego stulecia jak Henryk Ibsen (Hedda Gabler), Jens Bjørneboe (Til lykke med dagen, Tilfellet Torgersen, Dongery), Cecilie Løveid (Du, bli her!, Måkespisere, Vinteren revner) czy Jon Fosse (Gitarmannen, Nokon kjem til å komme, Dei døde hundane, Sa ka la). Przeanalizowane teksty wskazuja na duze zmiany w systemie adresatywnym: usunięcie z języka większości barier komunikacyjnych (nierówności w obrębie zaimków, tytułów, asymetrii płciowej i nadmiernej uczuciowości), co z jednej strony komunikację ułatwia, $z$ drugiej strony jednak egalitaryzacja nie wpływa na potrzeby społeczne samotnego człowieka, czyli jego chęć nawiazywania czy utrzymywania kontaktu.

Słowa kluczowe: dramat norweski, formy adresatywne, komunikacja, zmiany społeczne

\begin{abstract}
Forms of Address in the Context of More Open Society. A Study of 20th Century Norwegian Dramas

The aim of this article is to take a closer look at certain changes in social communication in Norway, connected to forms of address, that is words and expressions one uses to address his or her conversation partner(s). Since dramatic texts seem to be the most adequate material for this sort of research, because of the deictic expressions typical for spoken dialogue they contain (among others: pronouns and proper nouns), the material this research is based upon comes from selected dramatic texts written by such playwrights of the previous century as Henrik Ibsen (Hedda Gabler), Jens Bjørneboe (Til lykke med dagen, Tilfellet Torgersen, Dongery), Cecilie Løveid (Du, bli her!, Måkespisere, Vinteren revner) or Jon Fosse (Gitarmannen, Nokon
\end{abstract}


kjem til å komme, Dei døde hundane, Sa ka la). The analysed texts indicate significant changes in the addressative system: removal of most of the communicational barriers from the language (inequality regarding pronouns, titles, gender asymmetry and exaggerated emotionality), which, on the one hand, makes communication easier, and, on the other hand, one can consider that such egalitarisation does not influence the social needs of a solitary man or his/her willingness to establish or maintain contact.

Keywords: Norwegian drama, forms of address, communication, social changes

\section{Wstęp}

Norwegia jawi się większości jako kraj o mało znanej historii, leżący na Północy, którego rozwój ekonomiczny rozpoczęty w latach 70 . doprowadza nie tylko do dobrobytu, ale i bogactwa. Taki kierunek rozwoju nie skutkuje jednak w Norwegii podkreślaniem nierówności społecznych, ale wprost przeciwnie, niwelowanie ich na różnych płaszczyznach staje się jednym z celów norweskiej polityki. Dzisiejsza sytuacja społeczno-kulturowa w Norwegii została określona przez Agnes Fife, badaczkę owych relacji w Europie, mianem ,szacunku w egalitarnym odniesieniu"1 (1994: 28), który się przejawia na płaszczyźnie werbalnej między innymi zniknięciem dystansowych form adresatywnych, co jest rezultatem horyzontalnego układu społecznego (1994: 28).

W niniejszym artykule zamierzam przyjrzeć się zmianom w norweskim systemie adresatywnym jako jednym z nośników informacji o relacjach społecznych. W centrum mojego zainteresowania nie stoi jednak odpowiedź na pytanie, jak i kiedy dokonały się owe zmiany w rzeczywistości, ale jak owe zmiany w systemie stawały się widoczne w norweskich dramatach ostatniego stulecia. Dramaty są bowiem nasycone formami typowymi dla języka mówionego, stąd stanowią doskonały materiał do tego typu badań. Systemy adresatywne w dramatach wskażą więc, jak przebiegał proces zmian społecznych w Norwegii, owo zawarte w tytule otwieranie się norweskiego społeczeństwa.

Moje rozważania rozpoczynam definicją form adresatywnych według polskiego lingwisty, Eugeniusza Tomiczka:

Pod terminem FA [formy adresatywne - H. G.] rozumieć więc będziemy te wszystkie wypowiedzi performatywne, które za pomocą: 
- niektórych form pronominalnych - zaimki osobowe: w języku polskim TY, WY /rzadko: ON, ONA, ONI/ [...] - lub ich ekwiwalentów w postaci kategorii osobowej verbum finitum /wył. w j. pol./,

- form nominalnych: imię, nazwisko, odpowiednie podklasy tytulatury,

- form atrybutywnych: niektóre zaimki dzierżawcze i niektóre przymiotniki wraz z wariantami gradacyjnymi

oraz ich potencjalnych wzajemnych kombinacji służą nadawcy do nawiązania kontaktu językowego $\mathrm{z}$ adresatem/adresatami, podtrzymania tego kontaktu, jak również do określenia statusu społecznego wobec adresata/adresatów zgodnie z przyjętymi społecznymi normami kulturowymi i obyczajowymi decydującymi o stopniu i charakterze dystansu między partnerami aktu bezpośredniej komunikacji.

(Tomiczek 1983: 45)

Uzupełnieniem powyższej definicji są uwagi niemieckiej lingwistki Friederike Braun, która wspomina o możliwych różnicach pomiędzy znaczeniem leksykalnym form adresatywnych a cechami adresata. Braun także porządkuje typy form rzeczownikowych, wyróżniając między innymi takie kategorie jak: nazwy własne, określenia pokrewieństwa, formy ogólne (standardowe), szeroką kategorię tytułów, zwroty abstrakcyjne, nazwy zawodów i funkcji oraz afektonimy (Braun 1988: 7-11).

Związki między formami adresatywnymi a relacjami międzyludzkimi oraz miejscem rozmówców w hierarchii społecznej, były przedmiotem badań Rogera Browna i Alberta Gilmana, których socjolingwistyczna teoria rozpoczęła w latach 60. cykl studiów nad formami adresatywnymi. Zwrócili oni uwagę na związek systemów adresatywnych z hierarchią społeczną i wykazali, że wybór form jest zdeterminowany miejscem rozmówcy w społeczeństwie. Brown i Gilman wyróżnili dwa rodzaje stosunków międzyludzkich: power i solidarity (władza i solidarność/bliskość). W relacji power do osoby stojącej wyżej w hierarchii padają formy pełne szacunku, a do osoby stojącej niżej - deprecjonujące. Z kolei w relacji solidarity rozmówcy odgrywają taką samą lub zbliżoną rolę społeczną. Wtedy decydujące jest istnienie czynnika solidaryzującego; jeśli takowy istnieje, rozmówcy zwracają się do siebie za pomocą form bezdystansowych, ale jeżeli go brak, stosują formy dystansowe (Brown, Gilman 1966). Teoria Browna i Gilmana, ze względu na wskazywanie powiązań pomiędzy relacjami społecznymi i adresowaniem rozmówcy, stanowić będzie metodę badawczą, chociaż badacze koncentrowali się przede wszystkim na zaimkach, jedynie sygnalizując znaczenie pozostałych form adresatywnych ${ }^{2}$. 
Wspomniane $\mathrm{w}$ tytule sto lat zostaje potraktowane symbolicznie, ze względu na konieczność naszkicowania relacji społecznych typowych dla stanowo-klasowego społeczeństwa końca XIX w., które muszą stanowić punkt wyjścia do analizy. Jak wspomina historyk Rolf Danielsen (1991: 212), społeczeństwo norweskie nie stało się nigdy społeczeństwem typowo klasowym, tak jak i wcześniej nie było podzielone na wyraźnie wyodrębnione klasy społeczne, jednakże moment owego przejścia, a raczej długi i nieukończony proces przechodzenia, możemy prześledzić dzięki dramatom współczesnym Henryka Ibsena (1828-1906). Jak pisze Witold Nawrocki, Ibsen był „talentem pierwszej wielkości wśród plejady wybitnych pisarzy realistycznych” (1983: 94), a Bjørn Hemmer, wielki badacz twórczości i życia artysty, zwraca uwagę na jego głęboki związek ze współczesnością końca XIX w. i krytyczny - analityczny - stosunek do świata mieszczańskiego i jego wartości w świetle gwałtownych, pełnych konfliktu przemian (2003: 28). Ibsen podążał mianowicie drogą wytyczoną przez Georga Brandesa, słynnego duńskiego krytyka, według którego literatura miała pełnić określone zadanie: prowadzić debatę nad ważnymi współczesnymi sprawami społecznymi (1882: 26). Stąd możliwość potraktowania realiów dramatów współczesnych jako obrazu norweskiego świata tej epoki.

By zbadać zmiany zachodzące w norweskim społeczeństwie zaczynam więc moją analizę od przyjrzenia się formom adresatywnym w jednym z ostatnich dramatów Ibsena - Heddzie Gabler. Dramat ów powstał w 1890 r.

\section{Punkt wyjścia, czyli Hedda Gabler (Ibsen 1952)}

Formy adresatywne w tym dramacie są niezwykle bogate i zróżnicowane. Już w obrębie zaimków widzimy wyraźną opozycję: norweskie $d u$ (ty) ${ }^{3}$ jest przeciwstawione formie grzecznościowej De (pan, pani, państwo). Bezdystansowe ty pojawia się tam, gdzie nie ma dystansu w relacjach: pomiędzy mężem i żoną, bliskimi krewnymi, przyjaciółmi. Z kolei forma dystansowa pada pomiędzy obcymi sobie osobami oraz takimi, gdzie nie ma możliwości zmiany znajomości z formalnej, na bliższą, serdeczniejszą. Dominują formy zwrotne, informujące o symetrii w relacji - osoba tytułowana panią w ten sam sposób zwraca się do swojego rozmówcy (oczywiście uzależniając wybór formy od płci). Jednakże pojawia się na kartach dramatu także szczątkowa asymetria w relacji władzy, kiedy to pani zwraca się do służącej za pomocą ty, a w zamian otrzymuje od niej grzecznościowe pani. To jedyny relikt większej hierarchiczności z przeszłości - pozostałe osoby, chociaż także są pracodawcami lub 
przyjaciółmi pracodawców służącej, mówią do niej tak, jak ona zwraca się do nich - za pomocą formy dystansowej.

Ibsen także podkreśla znaczenie przejścia na ty, czyli zmiany definicji relacji na bliską. Skutki zmiany formy mają istotnie znaczenie społeczne - zostaje zdecydowanie skrócony dystans miedzy rozmówcami, co uprawnia ich do okazywania zachowaniem większej zażyłości.

Oprócz form zaimkowych dostrzegamy też wielkie bogactwo form rzeczownikowych. W relacjach bezdystansowych pojawia się imię, a także nazwisko. Występujące samodzielnie nazwisko to forma wskazująca na bliskość. Pojawia się ono albo między serdecznie zaprzyjaźnionymi mężczyznami, albo jest użyte asymetrycznie - przez kobiety w stosunku do ich mężów lub ukochanych. W rewanżu mężczyźni zwracają się do nich przy pomocy imienia. Nazwisko pojawia się też $w$ standardowych formach grzecznościowych, ale zawsze poprzedzone bądź tytułem, bądź herr/fru (pan/pani). W stosunku do kobiet obowiązuje jednak odmienność formy ze względu na stan cywilny: te niezamężne są tytułowane frøken (panna), mężatki i wdowy to fru (pani). Form standardowych jest wiele w tekście, jakby ciągle podkreślano dystans i miejsce $\mathrm{w}$ społecznej hierarchii. Z tych samych powodów prawdopodobnie pojawiają się również samodzielnie tytuły zawodowe i rodzinne. W dramacie odnajdziemy również wiele innych form rzeczownikowych i bardzo dużo przymiotnikowych, które albo występują osobno, jak kjoere (drogi, kochany), albo są częścią bardziej rozbudowanej formy, np. kjcere assessor Brack (drogi asesorze Brack). Wyjątkowe miejsce zajmie też zwrot trzecioosobowy, w Heddzie Gabler pojawiający się jedynie w stosunku do kobiet, wyrażający tutaj zwiększoną uprzejmość i dystans. Rzeczownik fruen (pani), syntaktycznie zintegrowany, wskazuje na zdecydowanie większy respekt niż zaimek De (pani), choć w języku polskim nie dostrzegamy w przekładzie żadnej różnicy.

Ten wypracowany przez społeczeństwo system jest jednak nieraz rozbijany przez pojawiające się formy społecznie nieakceptowane. Część z nich jest używana za zgodą adresowanego, niektóre bez niej, ale niezależnie od tego w dramacie pojawiają się liczne przejścia, gdyż użycie formy bezdystansowej jest uzależnione przede wszystkim od obecności osób trzecich - kiedy one się pojawiają, forma znowu będzie oficjalna, uznawana przez innych. Zwroty adresatywne tego typu padają z reguły z ust mężczyzn, narzucającym kobietom swoją bliskość. Same kobiety tak się nie zachowują, utrzymują dystans.

Szczególną rolę pełni powtarzanie form adresatywnych - zarówno zaimkowych, jak i rzeczownikowych. To zjawisko, dość powszechne w języku norweskim, służy przede wszystkim podkreślaniu bliskości, gdyż to najczęściej formy bezdystansowe pojawiają się, 
zgodnie z norweskimi zasadami językowymi, w tej samej wypowiedzi, ale już poza ramą zdaniową.

Tak rozbudowany system adresatywny może też wymusić sytuacje, kiedy rozmówcy unikają stosowania jakichkolwiek form. Wypowiedzi unikowe, poprawnie, choć nieraz z wielkim trudem zbudowane zdania, nie definiują relacji w ogóle. Zjawisko to może być spowodowane nieznajomością miejsca rozmówcy w społeczeństwie albo trudnością w zdefiniowaniu relacji, kiedy rozmówca raz już nie zaakceptował formy i w związku z tym nie wiadomo, jak się do niego zwracać, by kolejny raz nie doprowadzić do konfliktu.

Podsumowując analizę nie sposób nie zauważyć, jak silnie rozbudowany jest system form. Wyłania nam się z niego obraz wyjątkowo zhierarchizowanego społeczeństwa, gdzie każdy pełni określoną rolę i każdemu przysługuje w związku z tym określony tytuł. Konwenanse są bardzo utrwalone i widoczne, a wszelkiego rodzaju próby złamania zasad odbywają się jedynie na płaszczyźnie prywatnej i nierzadko są przyjmowane z niechęcią. Interesująca wydaje się więc odpowiedź na pytanie, co się stanie z tym zamkniętym społeczeństwem w następnych dziesięcioleciach.

\section{Autorzy, dramaty, zmiany}

By na to pytanie odpowiedzieć, należy przestudiować dramaty autorstwa wybitnych twórców norweskich dotyczące omawianego okresu. Jednym $\mathrm{z}$ wybranych dramatopisarzy reprezentatywnych dla analizowanych dziesięcioleci jest Cecilie Løveid, urodzona w $1951 \mathrm{r}$. Jak pisze Ewa Partyga: „Cecilie Løveid to jedna z najbardziej cenionych współczesnych pisarek norweskich, która od niemal trzydziestu lat pisze najrozmaitsze teksty dla teatru [...]” (2008: 8). Dla celów artykułu wybrałam Du, bli her! z 1980 r. (Løveid 1983a), Måkespisere 1980 (1983b), Vinteren revner 1983 (1983c). Kolejny twórca to już nieżyjący Jens Bjørneboe (1920-1976), twórca mało w Polsce znany,

w Norwegii zaś jego nazwisko urosło z czasem do rangi pewnego symbolu - Bjørneboe jest uznawany nie tylko za jednego z najwybitniejszych norweskich pisarzy XX wieku, ale też za jedną z najbarwniejszych postaci powojennego świata literackiego, bezkompromisowego buntownika, który zawsze stawał po stronie słabych i uciśnionych, nie bojąc się konfrontacji z instytucjami państwowymi, czy też konserwatywnymi normami współczesnego mu życia społecznego.

(Drozdowska 2018: 41) 
Wybrane dramaty to Til lykke med dagen z 1965 r. (Bjørneboe 2005a), Tilfellet Torgersen 1973 (2005b), Dongery 1976 (2005c). Kolejny dramatopisarz to Jon Fosse, urodzony w 1959 r., autor Gitarmannen z 1994 r. (Fosse 2005a), Nokon kjem til å komme 1996 (2004), Dei døde hundane 2003 (2005b), Sa ka la 2005 (2005c). „,Jon Fosse to najczęściej - po Ibsenie - grany dramaturg norweski” (Bjørneboe 2003: 102), zachwalany, ale i krytykowany przez krytyków zarówno w Norwegii, jak i na świecie.

Bohaterowie wspomnianych dramatów to albo ludzie współcześni, żyjący w rzeczywistości typowej dla czasu powstawania dramatu, albo ludzie żyjący w rzeczywistości minionej, ale nieodległej. W tym drugim przypadku jednoznaczne sygnały w tekście np. konkretne wydarzenia, łatwe do osadzenia w czasie, podany rok, czy sygnały bardziej ukryte, jak muzyka, popularna w danym okresie, wskazują na dziesięciolecie. To, że autorzy „cofają się w czasie" o niewiele lat, umożliwia im opis rzeczywistości i użycie form adresatywnych dobrze pamiętanych. Przy założeniu, że dramatopisarze nie chcieli świadomie wprowadzać form, które nie byłyby stosowane w danej epoce, możemy przyjąć, że opisywane relacje międzyludzkie prawdopodobnie odpowiadają tym z rzeczywistości. Oczywiście przy analizie należy być świadomym, że opisywane w poszczególnych dramatach relacje nie zawsze dotyczą tego samego typu osób (np. relacji mąż - żona), oraz że każdy autor dysponuje swoim specyficznym warsztatem, typowym tylko dla niego.

\subsection{Wojna - Måkespisere (Løveid 1983b)}

Nadal bardzo wyraźnie dostrzegamy opozycję pomiędzy zaimkami bezdystansowymi i dystansowymi. $D u$ (ty) pojawia się wśród członków rodziny i w czasie rozmów młodzieży, natomiast De (pan/pani/państwo) wtedy, kiedy adresowani są ludzie obcy, starsi czy odgrywający ważną rolę w społeczeństwie (zarówno pracodawca, jak i jego młody syn). Zaskakuje fakt, że pani używane jest także w wypowiedziach ordynarnych, nacechowanych seksualizmem, o ile osoba, do której zwraca się rozmówca, jest dorosła. W dramacie pojawia się jednak nowy zaimek, zaimek dere (wy) w funkcji grzecznościowej. Jak wspomina językoznawca August Western, nie jest to poprawne (1921: 434-435), ale w tym wypadku stanowi element idiolektu ludzi prostych z określonego regionu, jego obecność w tekście jest więc w pełni uzasadniona.

Oprócz zwrotów zaimkowych w dramacie wielokrotnie pada imię i nazwisko. To pierwsze dominuje jako forma intymna między przyjaciółkami oraz w relacji do dziecka; w rozmowie z dzieckiem pojawia się również zdrobnienie, nacechowane uczuciowością. Nazwiskiem z kolei 
adresuje żona męża tylko wtedy, kiedy jest na niego rozgniewana. W innych sytuacjach żona zwraca się do męża jedynie za pomocą zaimka ty.

Kolejne formy rzeczownikowe to tytuły rodzinne i zawodowe (np. mama, pan dyrektor teatru). Te zawodowe najczęściej poprzedza standardowe pan/pani, które również jest częścią składową form zawierających nazwiska - choć należy tu podkreślić, że więcej jest form tytularnych od form z nazwiskami. Podobnie jak w XIX w., także i tutaj kobiety są adresowane w zależności od swojego stanu cywilnego (podział na pani i panna), ale uwagę zwraca zupełnie nowa kwestia, a mianowicie obecność form deprecjonujących kobiety. Najczęściej jest to poprzedzenie nazwiska lub tytułu panna przymiotnikiem lille (mała), co wskazuje na lekceważenie dla rozmówczyni, ale w jednym przypadku pojawia się też imię Lili Marlen, poprzedzone tymże przymiotnikiem, określające pogardliwy stosunek rozmówcy do młodej, początkującej aktorki.

Okres wojny to czas nadal mocno zhierarchizowanych relacji społecznych. Ludzie zajmują przypisane im miejsce i są tytułowani odpowiednio do odgrywanej roli. Brak jednak formom owego wcześniejszego bogactwa, zniuansowania. Wygląda na to, że rola nazwiska jako intymnej formy męskiej - tylko męskiej - powoli się zmniejsza. Zwracają uwagę pojawiające się zdrobnienia, naładowane pozytywnymi uczuciami, jak i formy deprecjonujące w stosunku do kobiet, grupy poprzednio werbalnie szanowanej. Wszystko to może wskazywać na początek symetrii w relacjach kobieta - mężczyzna, oraz na branie pod uwagę uczuć, a nie tylko miejsca na społecznej drabinie. Nie można też nie zauważyć, że pojedynczo pojawiają się formy nie uznawane za poprawne, co świadczyć może o otwieraniu się na akceptację różnorodnych wariantów językowych.

\subsection{Lata 50. i 60. - Vinteren revner (Løveid 1983c), Til lykke med dagen (Bjørneboe 2005a), Tilfellet Torgersen (Bjørneboe 2005b)}

Pozornie nadal jest widoczna w tym okresie opozycja form zaimkowych: ty jest przeciwstawione pan/pani/państwo, ale ty zaczyna się też pojawiać w relacji zdominowanej przez semantykę władzy, i to zarówno w relacji nadrzędno-podrzędnej, jak i w podrzędnonadrzędnej. Należy jednak zauważyć, że owa bezdystansowa symetria we wspomnianej relacji występuje tylko nieoficjalnie; w sytuacji urzędowej obie strony posługują się formą grzecznościową. Również ponownie spotykamy w dramatach niepoprawną $\mathrm{w}$ standardzie formę wy jako formę grzecznościową dla 2. osoby liczby pojedynczej. Nie pada za to nazwisko jako męska forma bezdystansowa, jego miejsce przejmuje imię - również w relacjach 
pomiędzy mężczyznami - albo przydomek. W tekście pojawiają się liczne standardowe formy grzecznościowe, składające się z ogólnego pan/pani i tytułu lub nazwiska. Wyjątkowo forma adresatywna zawiera zarówno tytuł, jak i nazwisko, ale ma to miejsce głównie w sytuacji urzędowej. Nie brak też tytułów rodzinnych. Za to jedynie wyjątkowo pojawia się zwrot trzecioosobowy, głównie jako kpina z tytułu i/lub pozycji, oraz równie rzadko pojawiają się uniki. Obecne są nieliczne afektonimy oraz formy deprecjonujące.

Podsumowując lata 50. i 60., dostrzegamy pierwsze sygnały w obrębie opozycji zaimkowej, świadczące o przechodzeniu, na razie nieoficjalnym i odwracalnym, na formę bezdystansową, na ty. Chociaż pozycja w społeczeństwie nadal jest ważna, czego dowodzą pojawiające się różnorakie tytuły, to uczucia także wpływają na wybór formy. Nazwisko jako samodzielna forma bezdystansowa znika zupełnie $\mathrm{z}$ języka, formy padające między mężczyznami lub adresowane do mężczyzn przez kobiety to imię, tak samo jak w relacji kobieta - kobieta czy mężczyzna - kobieta. Wydaje się więc, że wyrównują się relacje między płciami, a rozbudowana poprzednio struktura społeczna zaczyna ulegać drobnym na razie zmianom.

\subsection{Lata 70. i 80. - Dongery (Bjørneboe 2005c), Du, bli her (Løveid 1983a)}

W omawianym okresie ponownie obserwujemy opozycję w obrębie zaimków, z formą ty do osób bliskich i członków rodziny, oraz z formą grzecznościową do osób, z którymi rozmówców łączą jedynie relacje oficjalne. Konsekwentnie jednak nie występuje w dramacie nazwisko męskie jako forma intymna, zamiast niego pojawia się jedynie imię. Za to nazwisko jest kilkakrotnie użyte w relacji władzy do osób stojących poniżej i to bez względu na ich płeć. Zastosowanie kobiecego nazwiska w takiej relacji jest niepoprawne (Brøgger 1960: 42), ale mamy tu do czynienia ze specyficznym żargonem będącym w użyciu w określonym miejscu pracy.

Z form rzeczownikowych w dramatach wiele jest złożonych tytułów zawodowych (np. pan kierownik sprzedaży), pojawiają się też tytuły rodzinne, a w oficjalnych relacjach do kobiet - złożenia składające się z formy pani i nazwiska. Także tylko kobiety są adresowane za pomocą zwrotów deprecjonujących.

W latach 70. i 80. w analizowanych dramatach ciągle dostrzegamy piramidę społeczną, ale uwagę zwraca zrównanie kobiety i mężczyzny w obrębie form bezdystansowych. Również nazwisko jako zwrot nadrzędno-podrzędny pojawia się w relacji do obu płci, ale jednak tylko w rozmowach z kobietami padają typowe formy deprecjonujące. Kobiety nadal są tą grupą, 
którą traktuje się z góry. Niepoprawność językowa także świadczy o otwieraniu się społeczeństwa na różnorodność, tutaj językową.

\subsection{Lata 90. - Gitarmannen (Fosse 2005a), Nokon kjem til å komme (Fosse 2004)}

Dramaty opisujące lata 90. zaskakują minimalizmem, jeśli przyglądamy się zwrotom adresatywnym. Jednak niezależnie od dużej oszczędności słowa cechą rzucającą się w oczy jest kompletny brak zaimka dystansowego De (pan/pani/państwo). Jedyną formę zaimkową stanowi bezdystansowe ty, pojawiające się w rozmowach zarówno między znajomymi, jak i nieznajomymi; między dorosłymi i dziećmi. W dramatach nie pojawia się żadna forma tytularna, brak jest również imion czy nazwisk - jedyny wyjątek to przezwisko Gitarmannen (gitarzysta), które dzieci nadają głównemu bohaterowi monodramu. Za to zaskakuje olbrzymia ilość uników, niechęć do zdefiniowania relacji, unikanie nazywania rozmówcy. Co więcej, owe uniki są nie tylko werbalne, ale i fizyczne - bohaterowie udają, że się nie widzą, odwracają się od siebie, chowają się za dom.

Różnica pomiędzy latami 90. i poprzednimi jest zaskakująca - mamy do czynienia ze społeczeństwem nieuznającym dystansu, egalitarnym, ludźmi, którzy nie używają zwrotów adresatywnych, by nie wartościować rozmówcy, by ukazywać równość. Z drugiej strony widzimy społeczeństwo, w którym człowiek unika nie tylko bliskości, ale nawet kontaktu z drugim człowiekiem. Pojawia się sprzeczność pomiędzy owym werbalnym „otwieraniem się” jednego człowieka na drugiego, wymazywaniem wszelakich różnic, a zamykaniem się na kontakt jako taki.

\subsection{Początek XXI wieku - Dei dode hundane (Fosse 2005b), Sa ka la (Fosse 2005c)}

Początek XXI w. nie różni się wiele od wcześniejszego okresu. Nadal nie dostrzeżemy opozycji zaimków, występuje jedynie ty, i nadal zaobserwujemy skromne występowanie form adresatywnych w ogóle. $Z$ form rzeczownikowych pojawi się jeden tytuł rodzinny, i to w zdrobnieniu mamma (mama/mamusia) oraz imię. $\mathrm{Za}$ to rozmówcy używają także naładowanych uczuciami przymiotników oraz licznych powtórzeń, które również podkreślają uczucia. Nadal pojawiają się uniki, i to zarówno na płaszczyźnie werbalnej, jak i niewerbalnej (unikanie adresowania rozmówcy, monosylaby w miejsce zdań, unikanie rozmowy w ogóle, odwracanie się, wychodzenie).

Różnice między zwrotami z lat 90. a tymi z początku XXI w. są więc niewielkie. Dostrzegamy brak społecznego dystansu i równość rozmówców; jedyna osoba tytułowana to 
krewna, czyli ktoś, komu taki tytuł się należy z powodów naturalnych. Od poprzedniego okresu ten się różni większą uczuciowością, ale nadal obecny jest chłód i nieotwieranie się na drugiego człowieka.

\section{Wnioski}

Podsumowując zmiany, które zaszły w języku norweskim w obrębie systemu adresatywnego ostatniego stulecia, a które pojawiły się w analizowanych dramatach, należy wymienić te najważniejsze:

- Stopniowe zanikanie opozycji w obrębie zaimków aż do kompletnego usunięcia zaimka dystansowego

- Zniknięcie nazwiska mężczyzny jako formy intymnej i pojawienie się w tej funkcji imienia (podobnie jak przy adresowaniu kobiet)

- Zniknięcie form standardowych, zarówno z nazwiskiem, jak i z tytułem

- Zniknięcie tytułów zawodowych (zostają jedynie rodzinne)

- Zniknięcie zróżnicowania tytułów kobiety w zależności od stanu cywilnego

- Zniknięcie form deprecjonujących

- Drastyczne zmniejszenie się ilości oraz zniuansowania form adresatywnych w ogóle.

Zmiany zachodzące $\mathrm{w}$ norweskim systemie adresatywnym ostatniego stulecia świadczą o znaczących zmianach w samym społeczeństwie Norwegii, które usunęło z języka takie istotne bariery komunikacyjne jak nierówność w obrębie zaimków (wszyscy zwracają się do siebie na ty), tytuły (wyjąwszy rodzinne), asymetrię płciową (brak różnic w zwracaniu się do kobiet i mężczyzn), nadmierną uczuciowość. Samo porozumiewanie wydaje się więc proste, pozbawione owych utrudnień, wynikających z nierówności, płci, zawodu czy wykształcenia. Jednak przy głębszym zastanowieniu się można dojść do wniosku, że owo wykreślenie barier również zubożyło społeczeństwo o możliwość wyrażania w sposób naturalny owych różnic. Bez wątpienia komunikacja bez barier współtworzy społeczeństwo otwarte na każdego, w którym to człowiek czuje się szanowany jako człowiek, a nie ze względu na wyraźnie określone miejsce w hierarchii. Z drugiej strony można jednak zauważyć, że brak barier nie oznacza lepszej komunikacji, gdyż otwartość społeczeństwa nie wpływa na otwartość samego człowieka, który unika kontaktu społecznego lub ogranicza go do minimum, wybierając dobrowolnie lub nie - samotność. 


\section{Przypisy}

${ }^{1} \mathrm{O}$ ile nie podano inaczej, cytaty w moim przekładzie.

${ }^{2}$ Podziału Browna i Gilmana na zaimki dystansowe i bezdystansowe nie da się jednak zastosować do wszystkich języków, na co zwraca uwagę np. Friederike Braun (Braun 1988) czy Romuald Huszcza (Huszcza 2006), ale pozostaje on dominującą metodą badawczą przy analizowaniu języków europejskich.

${ }^{3}$ Ponieważ wyrazistość form adresatywnych zostaje nieraz złagodzona lub zmieniona w przekładzie, posiłkuję się zawsze tekstem oryginalnym, a przekład dla celów artykułu jest mojego autorstwa, o ile nie podano inaczej.

\section{Bibliografia}

Bjørneboe, Jens (2005a) „Til lykke med dagen”. [W:] Jens Bjørneboe, Samlede skuespill.

Oslo: Pax Forlag A/S; 7-84.

Bjørneboe, Jens (2005b) „Tilfellet Torgersen”. [W:] Jens Bjørneboe, Samlede skuespill. Oslo:

Pax Forlag A/S; 299-411.

Bjørneboe, Jens (2005c) „Dongery”. [W:] Jens Bjørneboe, Samlede skuespill. Oslo: Pax

Forlag A/S; 413-454.

Bjørneboe, Therese (2003) „Jon Fosse på europeiske scener”. [W:] Samtiden 1/2003; 101-114.

Brandes, Georg (1882) Główne prądy literatury XIX stulecia. Prelekcje wykładane w

Uniwersytecie Kopenhagskim przez J. Brandesa, tom 1. Warszawa: Redakcya „Prawdy”.

Braun, Friederike (1988) Terms of Address. Problems of patterns and usage in various languages and cultures. Berlin - New York - Amsterdam: Mounton de Gruyter.

Brown, Roger, Albert Gilman (1966) „The Pronouns of Power and Solidarity”. [W:] Thomas

A. Sebeok (red.), Style in Language. Cambridge, Massachusetts: The M.I.T. PRESS,

Massachusetts Institute of Technology; 253-276.

Brøgger, Waldemar (red.) (1960) Skikk og bruk. Oslo: J. W. Cappelens Forlag.

Danielsen, Rolf et al. (1991) Grunntrekk i norsk historie. Fra vikingtid til våre dager. Oslo:

Universitetsforlaget.

Drozdowska, Karolina (2018) „Semmelweis Jensa Bjørneboe - bunt na wskroś czasu i

przestrzeni”. [W:] Czas kultury 2/2018; 40-47.

Fife, Agnes (1994) Kulturforskjeller i Europa. Oslo: Global.

Fosse, Jon (2004) Nokon kjem til å komme. Oslo: Det Norske Samlaget.

Fosse, Jon (2005a) „Gitarmannen”. [W:] Jon Fosse, Teaterstykke 3. Oslo: Det Norske

Samlaget; 7-44.

Fosse, Jon (2005b) „Dei døde hundane”. [W:] Jon Fosse, Teaterstykke 3. Oslo: Det Norske

Samlaget; 45-173. 
Fosse, Jon (2005c) „Sa ka la”. [W:] Jon Fosse, Teaterstykke 3. Oslo: Det Norske Samlaget; 175-277.

Hemmer, Bjørn (2003) Ibsen. Kunstnerens vei. Bergen: Vigmostad \& Bjørke.

Huszcza, Romuald (2006) Honoryfikatywność. Gramatyka, pragmatyka, typologia. Warszawa: Wydawnictwo Naukowe PWN.

Ibsen, Henrik (1952) „Hedda Gabler”. [W:] Henrik Ibsen, Samlede verker, t. 5. Oslo:

Gyldendal Norsk Forlag; 313-411.

Kołaczkowski, Andrzej M., Ryszard K. Nitschke (1983) „Literatura norweska”. [W:]

Władysław Floryan (red.) Dzieje literatur europejskich, t. 2. Warszawa: Państwowe Wydawnictwo Naukowe; 65-146.

Løveid, Cecilie (1983a) „Du, bli her!”. [W:] Cecilie Løveid, Måkespisere. Tre spill for radio og scene. Oslo: Gyldendal Norsk Forlag; 7-16.

Løveid, Cecilie (1983b) „Måkespisere”. [W:] Cecilie Løveid, Måkespisere. Tre spill for radio og scene. Oslo: Gyldendal Norsk Forlag; 17-51.

Løveid, Cecilie (1983c) „Vinteren revner”. [W:] Cecilie Løveid, Måkespisere. Tre spill for radio og scene. Oslo: Gyldendal Norsk Forlag; 53-84.

Partyga, Ewa (2008) „W poszukiwaniu «niezbędnego innego»”. [W:] Cecilie Løveid, Córy Renu i inne kobiety. Kraków: Panga Pank; 7-24.

Tomiczek, Eugeniusz (1983) System adresatywny współczesnego języka polskiego $i$ niemieckiego. Socjolingwistyczne studium konfrontatywne. Wrocław: Wydawnictwo Uniwersytetu Wrocławskiego.

Western, August (1921) Norsk riksmåls-grammatikk for studerende og loerere. Kristiania: H. Aschehoug \& CO. 